\title{
Virulence, agr groups, antimicrobial resistance and epidemiology of Staphylococcus aureus isolated from bovine subclinical mastitis
}

\section{Virulência, grupos agr, resistência a antimicrobianos e epidemiologia de isolados de Staphylococcus aureus obtidos de vacas com mastite}

\author{
Felipe Mendes Zorzi ${ }^{1}$ (D); Luiz Francisco Zafalon ${ }^{2}$ (D); Franklin Bispo Santos ${ }^{3}$ (D); Arthur Ferreira Borges ${ }^{4}$ (D); \\ Ticiano Gomes Nascimento ${ }^{4}$ (1); Irinaldo Diniz Basílio-Júnior ${ }^{4}$ (D); Elsa Masae Mamizuka ${ }^{5}$ (D); \\ Lara Mendes Almeida ${ }^{4,5}$ (1)
}

\begin{abstract}
${ }^{1}$ Universidade de São Paulo, Faculdade de Zootecnia e Engenharia de Alimentos, Medicina Veterinária e Zootecnia,, Pirassununga - SP, Brazil ${ }^{2}$ Empresa Brasileira de Pesquisa Agropecuária, Embrapa Pecuária Sudeste, São Carlos - SP, Brazil

${ }^{3}$ Universidade Federal de Alagoas, Complexo de Ciências Médicas, Arapiraca - AL, Brazil

${ }^{4}$ Universidade Federal de Alagoas, Instituto de Ciências Farmacêuticas, Maceió - AL, Brazil

${ }^{5}$ Universidade de São Paulo, Faculdade de Ciências Farmacêuticas, São Paulo - SP, Brazil
\end{abstract}

\begin{abstract}
Fifty-two Staphylococcus aureus recovered from papillary ostium and milk samples collected from cows with subclinical mastitis and milking environments in three small dairy herds located in southeastern Brazil were subjected to PCR identification based on the thermonuclease $(n u c)$ gene. All the strains were submitted to in vitro antimicrobial susceptibility testing, and we investigated the sequence types (STs), agr groups (I-IV), virulence genes encoding for Microbial Surface Components Recognizing Adhesive Matrix Molecules (MSCRAMMs), biofilm-associated proteins, bi-component toxins, pyrogenic toxin superantigens, and enterotoxins. Screening for oxacillin resistance $(2-6 \mu \mathrm{g} / \mathrm{ml}$ oxacillin), beta-lactamase activity assays, and PCR for the $m e c A / m e c C$ genes detected 26 methicillin-susceptible S. aureus (MSSA) and 26 mec-independent oxacillin-nonsusceptible S. aureus (MIONSA). While MSSA isolates were found to be susceptible to all antimicrobial agents tested, or only resistant to penicillin and ampicillin, MIONSA isolates were multidrug-resistant. ST126-agr group II MSSA isolates were prevalent in milk $(\mathrm{n}=14)$ and carried a broad set of virulence genes (clfA, clfB, eno, $f n b A, f i B$, icaA, icaD, lukED, hla, and $h l b$ ), as well as the ST126-agr group II MIONSA isolated from milking liners $(\mathrm{n}=1)$, which also carried the eta gene. ST1-agr group III MIONSA isolates $(\mathrm{n}=4)$ were found in papillary ostium and milk, but most MIONSA isolates $(n=21)$, which were identified in both papillary ostium and milking liners, were agr-negative and assigned to ST126. The agr-negative and agr group III lineages showed a low potential for virulence. Studies on the characterization of bovine-associated MSSA/MIONSA are essential to reduce S. aureus mastitis to prevent economic losses in dairy production and also to monitor the zoonotic potential of these pathogens associated with invasive infections and treatment failures in healthcare.
\end{abstract}

Keywords: MSSA. MIONSA. Accessory gene regulator (agr). Bovine mastitis.

\section{RESUMO}

Cinquenta e dois isolados de Staphylococcus aureus obtidos de amostras colhidas do óstio papilar, do leite de vacas com mastite subclínica e do ambiente de ordenha em três fazendas de rebanhos leiteiros localizadas no sudeste do Brasil foram identificados por PCR para o gene da termonuclease $(n u c)$. Todos os isolados foram testados para sensibilidade a antimicrobianos e foram investigados os sequence types (STs), grupos agr (I-IV) e genes de virulência que codificam Microbial Surface Components Recognizing Adhesive Matrix Molecules (MSCRAMMs), proteínas associadas a biofilme, toxinas bi-componentes, toxinas pirogênicas com propriedades de superantígenos e enterotoxinas. Triagem para detecção de resistência à oxacilina $(2-6 \mu \mathrm{g} / \mathrm{ml}$ oxacilina), ensaios de atividade de enzimas beta-lactamases e PCR para os genes mecA/mecC detectaram 26 estirpes de $S$. aureus sensíveis à meticilina (methicillin-susceptible S. aureus, MSSA) e 26 estirpes de $S$. aureus mec-negativas não sensíveis à meticilina (mec-independent oxacillin-nonsusceptible $S$. aureus, MIONSA). Enquanto os isolados MSSA foram sensíveis a todos os agentes antimicrobianos testados, ou apenas resistentes à penicilina e ampicilina, os isolados MIONSA foram multirresistentes. MSSA ST126-agr grupo II foram prevalentes no leite $(n=14)$ e apresentaram um amplo conjunto de genes de virulência (clfA, clfB, eno, fnbA, fiB, icaA, icaD, lukED, hla e $h l b)$, assim como o isolado MIONSA ST126-agr grupo II proveniente de um insuflador $(\mathrm{n}=1)$, o qual também apresentou o gene eta. MIONSA ST1-agr grupo III $(\mathrm{n}=4)$ foram identificados no óstio papilar e leite, mas a maioria dos 
isolados MIONSA ( $\mathrm{n}=21$ ), encontrados em óstios papilares e insufladores, foram agr-negativos e pertenceram ao ST126. As linhagens agr-negativas e agr grupo III apresentaram baixo potencial de virulência. Estudos sobre a caracterização de MSSA/MIONSA associados a bovinos são essenciais para a redução da mastite causada por S. aureus e de perdas econômicas na produção leiteira e, também, para o monitoramento do potencial zoonótico desses patógenos associados a infecções invasivas e falhas de tratamento em ambientes hospitalares.

Palavras-chave: MSSA. MIONSA. Accessory gene regulator (agr). Mastite bovina.

Correspondence to:

Lara Mendes Almeida

Universidade Federal de Alagoas, Instituto de Ciências

Farmacêuticas

Av. Lourival Melo Mota, s/n - Tabuleiro do Martins

CEP: 57072-900, Maceio - AL, Brazil

e-mail: larameal@gmail.com

Received: June 16, 2021

Approved: September 28, 2021

How to cite: Zorzi FM, Zafalon LF, Santos FB, Borges AF, Nascimento TG, Basílio-Júnior ID, Mamizuka EM, Almeida LM. Virulence, agr groups, antimicrobial resistance and epidemiology of Staphylococcus aureus isolated from bovine subclinical mastitis. Braz J Vet Res Anim Sci. 2021;58:e186701. https://doi.org/10.11606/ issn.1678-4456.bjvras.2021.186701

\section{Introduction}

Staphylococcus aureus has long been known as a cause of bovine intramammary infection (IMI) in dairy cattle worldwide (Barkema et al., 2006; Fitzgerald, 2012). $S$. aureus IMI leading to mastitis is favored by a set of the prolific genetic background of $S$. aureus genes encoding for Microbial Surface Components Recognizing Adhesive Matrix Molecules (MSCRAMMs), extracellular enzymes, exotoxins, bi-component toxins, and pyrogenic toxin superantigens (SAgs) (Foster et al., 2014). Virulence regulation in staphylococci has been mainly associated with the accessory gene-regulator (Agr) quorum-sensing system that functions based on the activity of two divergent transcripts regulated by two different promoters (P2 and P3) (Yarwood \& Schlievert, 2003). While the transcript RNAII encodes for components of the signaling system (AgrB, AgrD, AgrC, and AgrA), the 514 bp-small non-coding RNA (sRNA) (Benito et al., 2000), RNAIII, acts as an effector molecule in the staphylococcal agr locus, regulating the expression of virulence factors and heterogeneous resistance to antimicrobials as well (Abdelhady et al., 2015; Yarwood \& Schlievert, 2003). Four agr groups (I-IV) based on polymorphisms in the autoinducing peptides' (AIPs') amino acid sequences and the AgrC transmembrane receptor (Ji et al., 1997) have been associated with certain staphylococcal syndromes (Jarraud et al., 2002; Seidl et al., 2011; Painter et al., 2014). Nevertheless, autoinducing peptide variants other than those initially reported have also been identified in $S$. aureus isolates from cows with mastitis (Takeuchi et al., 2001), revealing the genetic heterogeneity of the agr locus.

Most livestock-associated (LA) S. aureus isolates causing IMI have emerged in several clonal clusters (CC) well-adapted to animal hosts. Of those, CC97, CC425, and CC705 appear to be restricted to the bovine host, whereas CC1, CC5, CC8, CC133, CC385, and CC398 have a broader host tropism (Fitzgerald, 2012; Smith et al., 2005). Virulence factors, antimicrobial resistance patterns, and agr types of bovine S. aureus lineages are critical for their adaptive evolution in the host, and insights into this can contribute to therapeutic intervention in cows with mastitis. To date, few studies on MLST-based phylogeny, in particular, studies on the bovine $S$. aureus agr locus have been carried out in Brazil. Here, we examined agr groups, selected virulence factors, antimicrobial susceptibility pattern, and sequence types (STs) of methicillin-susceptible $S$. aureus (MSSA) and mec-independent oxacillin-nonsusceptible $S$. aureus (MIONSA) isolated from bovine papillary ostium, mastitic cow's milk, and milking liners in dairy herds in southeastern Brazil.

\section{Material and Methods}

A convenience collection of $52 \mathrm{~S}$. aureus recovered from papillary ostium, milk, and milking liners in three small dairy herds located in São Paulo State, Brazil, was included in this study. Papillary ostium and milk samples were taken from cows that were previously diagnosed with subclinical mastitis by physical examination of the mammary glands, per the Ethics Committee on Animal Use guidelines (CEEA protocol number 034). Milk was sampled and stored following the National Mastitis Council procedures (National Mastitis Council, 2004) and then submitted for strip cup, California Mastitis Test (CMT), and SCC analyses (Schalm \& Noorlander, 1957). Only subclinical cases were included considering 200,000 cells/mL as the cut-off for the presence 
of subclinical mastitis (Pyörälä et al.,2003; Schukken et al., 2003; Oliveira et al., 2013), which has been demonstrated as a high sensitivity and specificity threshold for mastitis caused specifically by S. aureus (Dohoo et al., 2011). Swabs were collected from randomly selected milking liners in each farm and eight samples yielded colonies on blood agar (5\% sheep blood) at $37^{\circ} \mathrm{C}$. All colonies, including those from a culture of the papillary ostium and milk samples, were submitted to biochemical conventional assays for $S$. aureus screening (e.g. Gram stain, tube coagulase test, latex slide agglutination test, catalase, and DNase production) (Becker et al., 2015).

DNA of the $S$. aureus isolates was extracted using the DNeasy Blood and tissue kit (Qiagen, USA), with the addition of lysozyme $(50 \mathrm{mg} / \mathrm{ml})$ and lysostaphin
(10 $\mathrm{mg} / \mathrm{ml}$ ). For species confirmation, PCR assays for the $S$. aureus-specific thermonuclease $(n u c)$ gene were conducted. The agr groups were identified by an $a g r$ group-specific multiplex PCR as previously described (Gilot et al., 2002). Control strains were used as follows: $S$. aureus N315 (agr II), S. aureus ATCC 25923 (agr III), and S. aureus clinical strains from our laboratory collection (agr I, agr IV). Also, agr function was examined by determining delta-hemolysin activity (Seidl et al., 2011). The S. aureus strains RN6607 and RN9120 (RN6607 $\Delta a g r$ ) were used as positive and negative controls, respectively. Multiple virulence genes were assessed by PCR. All primer sets used in this study are included in Table 1 (Cucarella et al., 2001; Jarraud et al., 2002; Omoe et al., 2002; Tristan et al., 2003; Vasudevan et al., 2003).

Table 1 - Primers used in the PCR assays applied for the identification of Staphylococcus aureus isolated in dairy herds in SP state, Brazil

\begin{tabular}{|c|c|c|c|}
\hline Primer & F: sequence $\left(5^{\prime} \rightarrow 3^{\prime}\right)$ & R: sequence $\left(5^{\prime} \rightarrow 3^{\prime}\right)$ & References \\
\hline nuc & TATGGTCCTGAAGCAAGTG & GCCACGTCCATATTTATCAG & This study \\
\hline $\operatorname{mec} A$ & TGCTATCCACCCTCAAACAGG & AACGTTGTAACCACCCCAAGA & Kondo et al. (2007) \\
\hline mecC & GAAAAAAAGGCTTAGAACGCCTC & GAAGATCTTTTTCCGTTTTCAGC & García-Alvarez et al. (2011) \\
\hline Pan & ATGCACATGGTGCACATGC & & Gilot et al. (2002) \\
\hline $\operatorname{agr} 1$ & & GTCACAAGTACTATAAGCTGCGAT & Gilot et al. (2002) \\
\hline agr2 & & TATTACTAATTGAAAAGTGGCCATAGC & Gilot et al. (2002) \\
\hline agr3 & & GTAATGTAATAGCTTGTATAATAATACCCAG & Gilot et al. (2002) \\
\hline agr4 & & CGATAATGCCGTAATACCCG & Gilot et al. (2002) \\
\hline cflA & ATTGGCGTGGCTTCAGTGCT & CGTTTCTTCCGTAGTTGCATTTG & Tristan et al. (2003) \\
\hline$c f B$ & ACATCAGTAATAGTAGGGGGCAAC & TTCGCACTGTTTGTGTTTGCAC & Tristan et al. (2003) \\
\hline$f n b A$ & GTGAAGTTTTAGAAGGTGGAAAGATTAG & GCTCTTGTAAGACCATTTTTCTTCAC & Tristan et al. (2003) \\
\hline$f n b B$ & GTAACAGCTAATGGTCGAATTGATACT & CAAGTTCGATAGGAGTACTATGTTC & Tristan et al. (2003) \\
\hline$b b p$ & AACTACATCTAGTACTCAACAACAG & ATGTGCTTGAATAACACCATCATCT & Tristan et al. (2003) \\
\hline cna & GTCAAGCAGTTATTAACACCAGAC & AATCAGTAATTGCACTTTGTCCACTG & Tristan et al. (2003) \\
\hline eno & ACGTGCAGCAGCTGACT & CAACAGCATYCTTCAGTACCTTC & Tristan et al. (2003) \\
\hline$e b p$ & CATCCAGAACCAATCGAAGAC & CTTAACAGTTACATCATCATGTTTATCTTTG & Tristan et al. (2003) \\
\hline fib & CTACAACTACAATTGCCGTCAACAG & GCTCTTGTAAGACCATTTTCTTCAC & Tristan et al. (2003) \\
\hline$i c a A$ & CCTAACTAACGAAAGGTAG & AAGATATAGCGATAAGTGC & Vasudevan et al. (2003) \\
\hline$i c a D$ & AAACGTAAGAGAGGTGG & GGCAATATGATCAAGATAC & Vasudevan et al. (2003) \\
\hline bap & CCCTATATCGAAGGTGTAGAATTG & GCTGTTGAAGTTAATACTGTACCTGC & Cucarella et al. (2001) \\
\hline hla & CTGATTACTATCCAAGAAATTCGATTG & CTTTCCAGCCTACTTTTTTATCAGT & Jarraud et al. (2002) \\
\hline$h l b$ & GTGCACTTACTGACAATAGTGC & GTTGATGAGTAGCTACCTTCAGT & Jarraud et al. (2002) \\
\hline$h / g$ & GTCAYAGAGTCCATAATGCATTTAA & CACCAAATGTATAGCCTAAAGTG & Jarraud et al. (2002) \\
\hline tst & TTCACTATTTGTAAAAGTGTCAGACCCACT & TACTAATGAATTTTTTTTATCGTAAGCCCTT & Jarraud et al. (2002) \\
\hline$p v l$ & ATCATTAGGTAAAATGTCTGGACATGATCCA & GCATCAASTGTATTGGATAGCAAAAGC & Jarraud et al. (2002) \\
\hline lukDE & TGAAAAAGGTTCAAAGTTGATACGAG & TGTATTCGATAGCAAAAGCAGTGCA & Jarraud et al. (2002) \\
\hline lukMF & TGGATGTTACCTATGCAACCTAC & GTTCGTTTCCATATAATGAATCACTAC & Jarraud et al. (2002) \\
\hline eta & ACTGTAGGAGCTAGTGCATTTGT & TGGATACTTTTGTCTATCTTTTTCATCAAC & Jarraud et al. (2002) \\
\hline etb & CAGATAAAGAGCTTTATACACACATTAC & AGTGAACTTATCTTTCTATTGAAAAACACTC & Jarraud et al. (2002) \\
\hline sea & GAAAAAAGTCTGAATTGCAGGGAACA & CAAATAAATCGTAATTAACCGAAGGTTC & Jarraud et al. (2002) \\
\hline seb & ATTCTATTAAGGACACTAAGTTAGGGA & ATCCCGTTTCATAAGGCGAGT & Jarraud et al. (2002) \\
\hline sec & GTAAAGTTACAGGTGGCAAAACTTG & CATATCATACCAAAAAGTATTGCCGT & Jarraud et al. (2002) \\
\hline sed & GAATTAAGTAGTACCGCGCTAAATAATATG & GCTGTATTTTTCCTCCGAGAGT & Jarraud et al. (2002) \\
\hline see & CAAAGAAATGCTTTAAGCAATCTTAGGC & CACCTTACCGCCAAAGCTG & Jarraud et al. (2002) \\
\hline seg & AAGTAGACATTTTTGGCGTTCC & AGAACCATCAAACTCGTATAGC & Omoe et al. (2002) \\
\hline seh & GTCTATATGGAGGTACAACACT & GACCTTTACTTATTTCGCTGTC & Omoe et al. (2002) \\
\hline sei & GGTGATATTGGTGTAGGTAAC & ATCCATATTCTTTGCCTTTACCAG & Omoe et al. (2002) \\
\hline
\end{tabular}


Methicillin susceptibility of the $S$. aureus isolates was screened using Mueller-Hinton agar supplemented with $4 \% \mathrm{NaCl}$ containing $6 \mu \mathrm{g} / \mathrm{ml}$ of oxacillin at $37^{\circ} \mathrm{C}(24 \mathrm{~h})$, according to the Clinical and Laboratory Standards Institute guidelines (Clinical and Laboratory Standards Institute, 2018); $2-4 \mu \mathrm{g} / \mathrm{ml}$ of oxacillin were tested as well. S. aureus N315 (MRSA) and S. aureus ATCC 25923 (MSSA) were used as control strains. For detection of beta-lactamase production, nitrocefin-based enzyme activity assays (Cefinase; Becton-Dickinson Microbiology Systems, Cockeysville, MD, USA) were performed according to the manufacturer's instructions. Then, all $S$. aureus isolates were investigated for the presence of the mecA/mecC genes by PCR (GarcíaÁlvarez et al., 2011; Kondo et al., 2007).

Minimum inhibitory concentrations (MIC's) of penicillin, ampicillin, cephalothin, oxacillin, vancomycin, linezolid, chloramphenicol, florfenicol, tetracycline, erythromycin, azithromycin, tylosin, clindamycin, tigecycline, daptomycin, quinupristin-dalfopristin, ciprofloxacin, ofloxacin, nitrofurantoin, sulfonamide, sulfazotrin, streptomycin, amikacin, gentamicin, and kanamycin were determined using broth microdilution testing and interpreted according to the CLSI susceptibility breakpoints (Clinical and Laboratory Standards Institute, 2018). Isolates that exhibited resistance to three or more classes of antimicrobial agents in the phenotypic susceptibility testing were considered multidrug-resistant (MDR) (Magiorakos et al., 2012). The S. aureus ATCC strain 29213 was used as a control for antimicrobial susceptibility testing. Sequence types (STs) were determined using PubMLST (Jolley et al., 2018) and were assigned to clonal complexes (CC) using eBURST v3.

\section{Results and Discussion}

The MSSA isolates from milk ( $\mathrm{n}=12$ ) were susceptible to all antimicrobial agents tested, or exhibited resistance only to penicillin and ampicillin $(\mathrm{n}=14)$. On the other hand, 2 S. aureus isolated from milk and all S. aureus from papillary ostium $(\mathrm{n}=16)$ and milking liners $(\mathrm{n}=8)$ exhibited low-level oxacillin resistance and were MDR (Table 2). These MIONSA isolates were grown on oxacillin resistance screening agar using 2-6 $\mu \mathrm{g} / \mathrm{ml}$ oxacillin, exhibited oxacillin MIC's from 2 to $16 \mu \mathrm{g} / \mathrm{ml}$ by broth microdilution testing or Oxoid ${ }^{\circ}$ M.I.C. Evaluator strips, and were negative for the $m e c A / m e C$ genes by PCR. Non-penicillin-binding protein 2a (PBP2a)-mediated oxacillin resistance has been implicated in treatment failure of chronic MSSA infections with antistaphylococcal penicillins (Altman et al., 2018). It has been assigned to $\beta$-lactamase hyperproduction (borderline oxacillin-resistant $S$. aureus, BORSA) or adaptive mutations in PBPs (modified PBP S. aureus, MODSA) (Chambers, 1997), but recent studies have shown that other adaptive pathways under exposure to oxacillin also contribute to the MIONSA phenotype (Giulieri et al., 2020). $\beta$-lactamase production using nitrocefin disks was detected in 14 MSSA and all MIONSA isolates in this study, but none of them were considered to be hyper-producers using amoxicillin $(20 \mu \mathrm{g})$ and clavulanic acid $(10 \mu \mathrm{g})$ disks. The selective pressure due to the antimicrobial use in animal husbandry practices may have favored the emergence of resistances in the autochthonous microbiota of these herds or their milking environments. Moreover, these MIONSA isolates may have been selected by intramammary antimicrobial therapy (van den Borne et al., 2019), as dry cow therapy

Table 2 - MLST, agr group, virulence genes and antimicrobial susceptibility of MSSA and MIONSA investigation of Staphylococcus aureus isolated in dairy herds in SP state, Brazil

\begin{tabular}{|c|c|c|c|c|c|}
\hline Isolate & Origin & Agr group & ST & Virulence genes & Antimicrobial resistance \\
\hline MSSA (14) & Milk & II & 126 & $\begin{array}{l}\text { clfA, clfB, eno, fnbA, fib, } \\
\text { icaA, icaD lukED, hla, hlb }\end{array}$ & PEN, AMP \\
\hline MSSA (5) & Milk & negative & 126 & clfA, lukED & PEN, AMP \\
\hline MSSA (7) & Milk & negative & 126 & clfA, eno & \\
\hline MIONSA (1) & Milk & negative & 126 & clfA & PEN, AMP, KF, OXA, AK, DA, SUL \\
\hline MIONSA (2) & Milk & III & 1 & clfA & PEN, AMP, KF, OXA, AK, DA, SUL \\
\hline MIONSA (12) & Papillary ostium & negative & 126 & clfA & PEN, AMP, KF, OXA, AK, DA, SUL \\
\hline MIONSA (1) & Papillary ostium & negative & 126 & clfA, eta & PEN, AMP, KF, OXA, AK, DA, SUL, TET, ERY, AZI, CHL \\
\hline MIONSA (2) & Papillary ostium & III & 1 & clfA & PEN, AMP, KF, OXA, AK, DA, SUL \\
\hline MIONSA (1) & Milking liner & ॥ & 126 & $\begin{array}{l}\text { clfA, clfB, eno, fnbA, fib, } \\
\text { icaA, icaD, lukED, hla, } \\
\text { hlb, eta }\end{array}$ & PEN, AMP, KF, OXA, AK, DA, SUL \\
\hline MIONSA (4) & Milking liner & negative & 126 & clfA, icaA, icaD eta & PEN, AMP, KF, OXA, AK, DA, SUL, TET, ERY, AZI, CHL \\
\hline MIONSA (3) & Milking liner & negative & 126 & clfA & PEN, AMP, KF, OXA, AK, DA, SUL, TET \\
\hline
\end{tabular}

PEN, penicillin; AMP, ampicillin; KF, cephalothin; OXA, oxacillin; AK, amikacin; DA, clindamycin; SUL, sulfonamide; TET, tetracycline; ERY, erythromycin; AZI, azithromycin; CHL chloramphenicol. 
using cloxacillin was a common practice for control of mastitis among these herds.

The most prevalent agr group found among the MSSA and MIONSA isolates of this study were $a g r-I I \quad(n=15)$, followed by agr-III $(\mathrm{n}=4)$. No agr group could be assigned to 12 MSSA or 21 MIONSA isolates (Table 2). While agr-II strains were carriers of a broad set of genes encoding for MSCRAMMs, extracellular proteins, and cytolytic toxins, agr-III and non-typeable strains had a lower potential for virulence.

All MSSA and MIONSA isolates, regardless of the agr group, carried the gene encoding for the fibrinogen-binding MSCRAMM protein ClfA (clumping factor A). ClfA binding occurs via the fibrinogen $\gamma$-chain, which allows the interaction of $S$. aureus to various hosts (Geoghegan et al., 2010). The cell wall-anchored (CWA) protein ClfA promotes inhibition of opsonophagocytosis, and S. aureus adhesion to host blood proteins and biomaterial surfaces (Foster et al., 2014), which has recently been shown to occur under physiological stress (Herman-Bausier et al., 2018). clfA-carrying MSSA and MIONSA isolates were recovered from papillary ostium, milk, and milking liners, suggesting a crucial role of this surface adhesin in determining $S$. aureus IMI and enhancing the persistence of the pathogen in these milking environments.

In addition to $c l f A$, all agr-II strains carried other MSCRAMM genes, such as clfB (clumping factor B), fib (fibrinogen-binding protein), $f n b A$ (fibronectin-binding protein A), and eno (laminin-binding protein). These CWA proteins can determine the virulence of $S$. aureus lineages, as they are involved in the adhesion and invasion of host tissues, evasion of an immune response, and biofilm formation (Foster et al., 2014). The intercellular adhesion (ica) locus required to mediate cell-to-cell adhesion and polysaccharide intercellular adhesin (PIA) production was also identified in all agr-II strains, supporting their potential for biofilm production. Moreover, agr-II strains harbored genes encoding for the bicomponent pore-forming toxin LukED, alpha-toxin Hla, and beta-toxin Hlb. Leukotoxin $\mathrm{ED}$, which is encoded in the pathogenicity island $\nu \mathrm{Sa} \beta$, can damage bovine neutrophils by targeting CXCR2 as a receptor (Reyes-Robles et al., 2013). The leukotoxic action of S. aureus may be further accentuated by the pore-forming toxin Hla and sphingomyelinase $\mathrm{Hlb}$ expression, cytolytic toxins that are also involved with $S$. aureus adhesion to epithelial cells of bovine mammary glands (Cifrian et al., 1996).

Agr-II strains isolated from milking liners ( $\mathrm{n}=1)$, but not from milk, carried the eta gene encoding exfoliative toxin A (ETA). agr-negative S. aureus isolated from milking liners $(\mathrm{n}=4)$ and papillary ostium $(\mathrm{n}=1)$ were also positive for $\mathrm{eta}$. The extracellular protein encoded by the prophage ETA is responsible for the staphylococcal scalded-skin syndrome (SSSS) in S. aureus human infections. However, there is a genetic heterogeneity among temperate phages (phiETA), and bovine $S$. aureus isolates have already been able to produce ETA after being lysogenized by a yet undescribed lineage of an eta-converting phage (Endo et al., 2003). Therefore, bovine $S$. aureus pathogenicity might be enhanced by replication of phiETA in milking environments.

No MSSA or MIONSA isolates in this study possessed the MSCRAMM genes $c l f B$ (receptor for fibrinogen), $b b p$ (receptor for bone sialoprotein), ebpS (elastinbinding protein), $c n a$ (collagen-binding protein), or $f n b B$ (fibronectin-binding protein). Neither did the isolates possess the biofilm-associated gene bap, genes for the bicomponent pore-forming toxins LukAB, $\gamma$-hemolysin, LukMF', and Panton-Valentine leukocidin (PVL), the exfoliative gene $e t b$, the toxic shock syndrome toxin-1 gene (tst) or genes for the enterotoxins SEA-E and SEG-I.

Analysis of MLST-based phylogeny showed the occurrence of ST126 and ST1. The agr-II MSSA isolates were assigned to ST126 (CC97). CC97-associated S. aureus lineages have been mainly associated with bovine infections (Fitzgerald, 2012; Smith et al., 2005), but have also emerged as a cause of healthcare-related infections. ST126 lineages appear to be well adapted and so far restricted to cows (Fitzgerald, 2012; Smith et al., 2005). Identification of ST126-agr group II MSSA, most common in this study, raises concern over the livestock, as they were found to contain a significant set of virulence genes. The agr-defective MSSA and MIONSA isolates were assigned to ST126 and also to ST1, which has been implicated in causing infections in multiple host species (Fitzgerald, 2012). Even though agr-defective S. aureus strains are known to have attenuated virulence, studies have shown that agr dysfunction may arise and provide advantages to the pathogen, such as enhanced biofilm formation or polystyrene adherence during nosocomial infections (Shopsin et al., 2008).

The collection of isolates examined in this study was relatively small and restricted to the same geographic area, which limited inferring whether ST126-agr group II MSSA or MIONSA isolates would be endemic to certain regions or disseminated in dairy farms throughout the country, which may be considered limitations of the current study.

The present study provides data on the epidemiology and pathogenesis of $S$. aureus lineages involved in bovine mastitis in Brazil, which is indeed critical for developing effective strategies to reduce $S$. aureus IMI. Moreover, we 
report the mec gene-independent low-level oxacillin resistance phenotype in S. aureus isolated in papillary ostium, milk, and milking liners. Understanding how oxacillin resistance adaptation arises in bovine $S$. aureus is also crucial for the effectiveness of mastitis treatment.

\section{Conflict of interest}

The authors declare there is no conflict of interests.

\section{References}

Abdelhady W, Chen L, Bayer AS, Seidl K, Yeaman MR, Kreiswirth BN, Xiong YQ. Early agr activation correlates with vancomycin treatment failure in multi-clonotype MRSA endovascular infections. J Antimicrob Chemother. 2015;70(5):1443-52. http://dx.doi.org/10.1093/jac/dku547. PMid:25564565.

Altman DR, Sullivan MJ, Chacko KI, Balasubramanian D, Pak TR, Sause WE, Kumar K, Sebra R, Deikus G, Attie O, Rose H, Lewis M, Fulmer Y, Bashir A, Kasarskis A, Schadt EE, Richardson AR, Torres VJ, Shopsin B, van Bakel H. Genome Plasticity of agr-Defective Staphylococcus aureus during Clinical Infection. Infect Immun. 2018;86(10):e00331-18. http://dx.doi.org/10.1128/IAI.00331-18. PMid:30061376.

Barkema HW, Schukken YH, Zadoks RN. Invited Review: the role of cow, pathogen, and treatment regimen in the therapeutic success of bovine Staphylococcus aureus mastitis. J Dairy Sci. 2006;89(6):1877-95. http://dx.doi.org/10.3168/ jds.S0022-0302(06)72256-1. PMid:16702252.

Becker K, Skov RL, von Eiff C. Staphylococcus, micrococcus, and other catalase-positive cocci. In: Jorgensen JH, Carroll KC, Funke G, Pfaller MA, Landry ML, Richter SS, Warnock DW, editors. Manual of clinical microbiology. Hoboken: John Wiley \& Sons, Ltd; 2015. p. 354-82. http://dx.doi. org/10.1128/9781555817381.ch21.

Benito Y, Kolb FA, Romby P, Lina G, Etienne J, Vandenesch F. Probing the structure of RNAIII, the Staphylococcus aureus agr regulatory RNA, and identification of the RNA domain involved in repression of protein A expression. RNA. 2000;6(5):668-79. http://dx.doi.org/10.1017/ S1355838200992550. PMid:10836788.

Chambers HF. Methicillin resistance in staphylococci: molecular and biochemical basis and clinical implications. Clin Microbiol Rev. 1997;10(4):781-91. http://dx.doi. org/10.1128/CMR.10.4.781. PMid:9336672.

\section{Ethics Statement}

The research was conducted under the approval of the Ethics Committee on Animal Use guidelines (CEEA protocol number 034).

\section{Acknowledgements}

We thank our collaborators for providing the isolate collection analyzed in this study.

Cifrian E, Guidry AJ, Bramley AJ, Norcross NL, BastidaCorcuera FD, Marquardt WW. Effect of staphylococcal beta toxin on the cytotoxicity, proliferation and adherence of Staphylococcus aureus to bovine mammary epithelial cells. Vet Microbiol. 1996;48(3-4):187-98. http://dx.doi. org/10.1016/0378-1135(95)00159-X. PMid:9054116.

Clinical and Laboratory Standards Institute - CLSI. Performance standards for antimicrobial disk and dilution susceptibility tests for bacteria isolated from animals. 4th ed. Wayne, PA: CLSI; 2018. CLSI supplement VET08.

Cucarella C, Solano C, Valle J, Amorena B, Lasa I, Penadés JR. Bap, a Staphylococcus aureus surface protein involved in biofilm formation. J Bacteriol. 2001;183(9):2888-96. http:// dx.doi.org/10.1128/JB.183.9.2888-2896.2001. PMid:11292810.

Dohoo IR, Smith J, Andersen S, Kelton DF, Godden S. Diagnosing intramammary infections: evaluation of definitions based on a single milk sample. J Dairy Sci. 2011;94(1):250-61. http://dx.doi.org/10.3168/jds.20103559. PMid:21183035.

Endo Y, Yamada T, Matsunaga K, Hayakawa Y, Kaidoh T, Takeuchi S. Phage conversion of exfoliative toxin A in Staphylococcus aureus isolated from cows with mastitis. Vet Microbiol. 2003;96(1):81-90. http://dx.doi.org/10.1016/ S0378-1135(03)00205-0. PMid:14516710.

Fitzgerald JR. Livestock-associated Staphylococcus aureus: origin, evolution and public health threat. Trends Microbiol. 2012;20(4):192-8. http://dx.doi.org/10.1016/j.tim.2012.01.006. PMid:22386364.

Foster TJ, Geoghegan JA, Ganesh VK, Höök M. Adhesion, invasion and evasion: the many functions of the surface proteins of Staphylococcus aureus. Nat Rev Microbiol. 2014;12(1):49-62. http://dx.doi.org/10.1038/nrmicro3161. PMid:24336184. 
García-Álvarez L, Holden MTG, Lindsay H, Webb CR, Brown DFJ, Curran MD, Walpole E, Brooks K, Pickard DJ, Teale C, Parkhill J, Bentley SD, Edwards GF, Girvan EK, Kearns AM, Pichon B, Hill RLR, Larsen AR, Skov RL, Peacock SJ, Maskell DJ, Holmes MA. Meticillin-resistant Staphylococcus aureus with a novel mecA homologue in human and bovine populations in the UK and Denmark: a descriptive study. Lancet Infect Dis. 2011;11(8):595603. http://dx.doi.org/10.1016/S1473-3099(11)70126-8. PMid:21641281.

Geoghegan JA, Ganesh VK, Smeds E, Liang X, Höök M, Foster TJ. Molecular characterization of the interaction of staphylococcal microbial surface components recognizing adhesive matrix molecules (MSCRAMM) ClfA and Fbl with fibrinogen. J Biol Chem. 2010;285(9):6208-16. http:// dx.doi.org/10.1074/jbc.M109.062208. PMid:20007717.

Gilot P, Lina G, Cochard T, Poutrel B. Analysis of the genetic variability of genes encoding the RNA III-activating components Agr and TRAP in a population of Staphylococcus aureus strains isolated from cows with mastitis. J Clin Microbiol. 2002;40(11):4060-7. http://dx.doi.org/10.1128/ JCM.40.11.4060-4067.2002. PMid:12409375.

Giulieri SG, Guérillot R, Kwong JC, Monk IR, Hayes AS, Daniel D, Baines S, Sherry NL, Holmes NE, Ward P, Gao W, Seemann T, Stinear TP, Howden BP. Comprehensive Genomic investigation of adaptive mutations driving the low-level oxacillin resistance phenotype in Staphylococcus aureus. MBio. 2020;11(6):e02882-20. http://dx.doi.org/10.1128/ mBio.02882-20. PMid:33293382.

Herman-Bausier P, Labate C, Towell AM, Derclaye S, Geoghegan JA, Dufrêne YF. Staphylococcus aureus clumping factor A is a force-sensitive molecular switch that activates bacterial adhesion. Proc Natl Acad Sci USA. 2018;115(21):5564-9. http://dx.doi.org/10.1073/pnas.1718104115. PMid:29735708.

Jarraud S, Mougel C, Thioulouse J, Lina G, Meugnier H, Forey F, Nesme X, Etienne J, Vandenesch F. Relationships between Staphylococcus aureus genetic background, virulence factors, agr groups (alleles), and human disease. Infect Immun. 2002;70(2):631-41. http://dx.doi.org/10.1128/ IAI.70.2.631-641.2002. PMid:11796592.

Ji G, Beavis R, Novick RP. Bacterial interference caused by autoinducing peptide variants. Science. 1997;276(5321):202730. http://dx.doi.org/10.1126/science.276.5321.2027. PMid:9197262.

Jolley KA, Bray JE, Maiden MCJ. Open-access bacterial population genomics: BIGSdb software, the PubMLST.org website and their applications. Wellcome Open Res. 2018;3:124. http://dx.doi.org/10.12688/wellcomeopenres.14826.1. PMid:30345391.

Kondo Y, Ito T, Ma XX, Watanabe S, Kreiswirth BN, Etienne J, Hiramatsu K. Combination of multiplex PCRs for staphylococcal cassette chromosome mec type assignment: rapid identification system for mec, ccr, and major differences in junkyard regions. Antimicrob Agents Chemother. 2007;51(1):264-74. http://dx.doi.org/10.1128/ AAC.00165-06. PMid:17043114.

Magiorakos A-P, Srinivasan A, Carey RB, Carmeli Y, Falagas ME, Giske CG, Harbarth S, Hindler JF, Kahlmeter G, OlssonLiljequist B, Paterson DL, Rice LB, Stelling J, Struelens MJ, Vatopoulos A, Weber JT, Monnet DL. Multidrug-resistant, extensively drug-resistant and pandrug-resistant bacteria: an international expert proposal for interim standard definitions for acquired resistance. Clin Microbiol Infect. 2012;18(3):268-81. http://dx.doi.org/10.1111/j.14690691.2011.03570.x. PMid:21793988.

National Mastitis Council. Microbiological Procedures for use in the diagnosis of bovine udder infection and determination of milk quality. 4 th ed. Verona, WI: National Mastitis Council; 2004.

Oliveira L, Hulland C, Ruegg PL. Characterization of clinical mastitis occurring in cows on 50 large dairy herds in Wisconsin. J Dairy Sci. 2013;96(12):7538-49. http://dx.doi. org/10.3168/jds.2012-6078. PMid:24119795.

Omoe K, Ishikawa M, Shimoda Y, Hu D-L, Ueda S, Shinagawa K. Detection of seg, seh, and sei genes in Staphylococcus aureus isolates and determination of the enterotoxin productivities of $\mathrm{S}$. aureus isolates Harboring seg, seh, or sei genes. J Clin Microbiol. 2002;40(3):857-62. http://dx.doi. org/10.1128/JCM.40.3.857-862.2002. PMid:11880405.

Painter KL, Krishna A, Wigneshweraraj S, Edwards AM. What role does the quorum-sensing accessory gene regulator system play during Staphylococcus aureus bacteremia? Trends Microbiol. 2014;22(12):676-85. http://dx.doi.org/10.1016/j. tim.2014.09.002. PMid:25300477.

Pyörälä S. Indicators of inflammation in the diagnosis of mastitis. Vet Res. 2003;34(5):565-78. http://dx.doi. org/10.1051/vetres:2003026. PMid:14556695.

Reyes-Robles T, Alonzo F 3rd, Kozhaya L, Lacy DB, Unutmaz D, Torres VJ. Staphylococcus aureus leukotoxin ED targets the chemokine receptors CXCR1 and CXCR2 to kill leukocytes and promote infection. Cell Host 
Microbe. 2013;14(4):453-9. http://dx.doi.org/10.1016/j. chom.2013.09.005. PMid:24139401.

Schalm OW, Noorlander DO. Experiments and observations leading to development of the California mastitis test. J Am Vet Med Assoc. 1957;130(5):199-204. PMid:13416088.

Schukken YH, Wilson DJ, Welcome F, Garrison-Tikofsky L, Gonzalez RN. Monitoring udder health and milk quality using somatic cell counts. Vet Res. 2003;34(5):579-96. http://dx.doi.org/10.1051/vetres:2003028. PMid:14556696.

Seidl K, Chen L, Bayer AS, Hady WA, Kreiswirth BN, Xiong YQ. Relationship of agr expression and function with virulence and vancomycin treatment outcomes in experimental endocarditis due to methicillin-resistant Staphylococcus aureus. Antimicrob Agents Chemother. 2011;55(12):5631-9. http://dx.doi.org/10.1128/AAC.0525111. PMid:21968365.

Shopsin B, Drlica-Wagner A, Mathema B, Adhikari RP, Kreiswirth BN, Novick RP. Prevalence of agr dysfunction among colonizing Staphylococcus aureus strains. J Infect Dis. 2008;198(8):1171-4. http://dx.doi.org/10.1086/592051. PMid:18752431.

Smith EM, Green LE, Medley GF, Bird HE, Fox LK, Schukken YH, Kruze JV, Bradley AJ, Zadoks RN, Dowson CG. Multilocus sequence typing of intercontinental bovine Staphylococcus aureus isolates. J Clin Microbiol. 2005;43(9):4737-43. http://dx.doi.org/10.1128/JCM.43.9.4737-4743.2005. PMid:16145135.
Takeuchi S, Maeda T, Hashimoto N, Imaizumi K, Kaidoh T, Hayakawa Y. Variation of the agr locus in Staphylococcus aureus isolates from cows with mastitis. Vet Microbiol. 2001;79(3):267-74. http://dx.doi.org/10.1016/S03781135(00)00354-0. PMid:11240104.

Tristan A, Ying L, Bes M, Etienne J, Vandenesch F, Lina G. Use of multiplex PCR to identify Staphylococcus aureus adhesins involved in human hematogenous infections. J Clin Microbiol. 2003;41(9):4465-7. http://dx.doi.org/10.1128/ JCM.41.9.4465-4467.2003. PMid:12958296.

van den Borne BHP, van Schaik G, Lam TJGM, Nielen M, Frankena K. Intramammary antimicrobial treatment of subclinical mastitis and cow performance later in lactation. J Dairy Sci. 2019;102(5):4441-51. http://dx.doi.org/10.3168/ jds.2019-16254. PMid:30827563.

Vasudevan P, Nair MKM, Annamalai T, Venkitanarayanan KS. Phenotypic and genotypic characterization of bovine mastitis isolates of Staphylococcus aureus for biofilm formation. Vet Microbiol. 2003;92(1-2):179-85. http://dx.doi.org/10.1016/ S0378-1135(02)00360-7. PMid:12488081.

Yarwood JM, Schlievert PM. Quorum sensing in Staphylococcus infections. J Clin Invest. 2003;112(11):1620-5. http://dx.doi. org/10.1172/JCI200320442. PMid:14660735.

Financial Support: This project was supported by Grant numbers 2017/08979-7 and 2004/09253-0, São Paulo Research Foundation (FAPESP). It was financed in part by the Coordination for the Improvement of Higher Education Personnel (CAPES), Brazil - Finance code 001. 